\title{
A morte do poeta: Benjamin leitor de Hölderlin
}

The Poet's Death: Benjamin Reader of Hölderlin

\author{
Ulisses Razzante Vaccari \\ Professor Adjunto do Departamento de Filosofia \\ Universidade Federal de Santa Catarina [UFSC]
}

\section{RESUMO}

$\mathrm{O}$ artigo, num primeiro momento, busca contextualizar as condiçóes de surgimento do ensaio Dois poemas de Friedrich Hölderlin, de Benjamin, recorrendo a alguns fatos históricos, como a morte de seu amigo Fritz Heinle e Nobert von Hellingrath. Ligadas ao estopim da Primeira Guerra Mundial, tais mortes representam para Benjamin a morte de toda uma geração de jovens, na qual ele havia depositado toda a esperança de renascimento da cultura alemá. A leitura que faz de Hölderlin, nesse sentido, tem um fim político, ao procurar combater uma interpretação esteticizante de seus poemas, influenciada pelo círculo de Stefan George. Num segundo momento, o artigo aprofunda a leitura do ensaio de Benjamin sobre Hölderlin, buscando definir o conceito de "poetificado" como conceito central de sua crítica de arte, evidenciando em que medida esse conceito lhe serve como contraposiçáo às leituras provenientes do círculo de George, entre elas, a do próprio Hellingrath.

\section{PALAVRAS-CHAVE}

Morte do poeta; Bela aparência; Poetificado; Sublime.

\begin{abstract}
The article, at first, seeks to contextualize the conditions for the appearance of Benjamin's Two poems of Friedrich Hölderlin, using some historical facts, such as the death of his friend Fritz Heinle and Nobert von Hellingrath. Linked to the trigger of World War I, these deaths represent for Benjamin the death of an entire generation of young men, in whom he had placed all hope of revival of German culture. Hölderlin's reading in this sense has a political end in seeking to counteract a aestheticizing interpretation of his poems, influenced by Stefan George's circle. In a second moment, the article deepens the reading of Benjamin's essay on Hölderlin, seeking to define the concept of "poetized" as a central concept of his art criticism, showing to what extent this concept serves as a counterpoint to the readings from the circle of George among them Hellingrath's own.
\end{abstract}

\section{KEY WORDS}

Poet's Death; Beautiful Appearance; Poetified; Sublime. 
...para nós, o trágico consiste no fato de nos afastarmos do reino dos vivos, de modo inteiramente silencioso, empacotados numa caixa qualquer, e não de sermos devorados pelas chamas que não soubemos amestrar.

Hölderlin, carta a Böhlendorff, 4 de dezembro de I8OI

Hoje, a morte é cada vez mais expulsa do universo dos vivos.

Walter Benjamin, O Narrador

\section{A morte de Fritz Heinle e a poetização da guerra}

Em Geschichte einer Freundschaft, Gerschom Scholem indica que Benjamin conhecia a obra de Hölderlin desde sua mais tenra juventude, antes mesmo da publicação da edição crítica de suas obras em 1913 por Norbert von Hellingrath. Na primeira ocorrência desse contato registrada em seu livro (cf. Scholem, 20I6, p. 23), o autor relembra ter visto sobre a mesa de trabalho de Benjamin, em I915, a edição das obras de Hölderlin publicada em 1905 pela Insel Verlag ${ }^{1}$, ao lado de obras de Baudelaire, Píndaro e Mörike (cf. ibid., p. 25). Em Metafísica da Juventude, porém, observa-se que o contato de Benjamin com Hölderlin é ainda anterior a este ano de I9I5. Escrito entre I9I3 e I9I4, o ensaio, considerado dos mais importantes de sua produção juvenil, traz como epígrafe os seguintes versos do poema $O$ Aedo Cego, de Hölderlin: "Onde estás, Juventude! Que sempre / me desperta nas horas matinais, onde estás Luz?”2 (apud Benjamin, 20I5, vol. III, p. 65). Em Hölderlin, Benjamin busca um fundamento poético para sua filosofia ainda em formaçáo, cujo traço principal repousa no despertar metafísico de uma juventude anestesiada pela educação transmitida na universidade e pelo modelo de família burguesa. Essas duas instituiçóes — universidade e família —, ao cindir Eros produtor e reprodutor, privavam a juventude daquele erotismo socrático ${ }^{3}$ táo necessário para o verdadeiro conhecimento, que resultava assim sem vida e sem espírito, transformado num "saber" meramente

1 Trata-se da edição de Paul Ernst e Wilhelm Böhm. Incompleta, esta edição não trazia publicadas as conhecidas traduçóes de Sófocles, nem os hinos tardios de Hölderlin, escritos após I802, o que só será feito na edição crítica organizada por Norbert von Hellingrath. O presente texto abordará a relação de Benjamin com Hellingrath a seguir.

2 Em O conceito de crítica de arte no romantismo alemão, Benjamin cita uma variante desses versos de Hölderlin, retirada do poema Quiron, de I8or: "Onde estás tu, pensador!, que sempre tens que / Passar ao lado, em tempos, onde estás tu, luz?” (Benjamin, I993, p. 108).

3 Cf. para isso os textos Romantismo (Benjamim, 20I3, pp. 53-58), Educação Erótica (In: Benjamin, 20I5, vol. III, pp. 45-46) e Sócrates (In: Benjamin, 2015, vol. III, pp. I03-IO6). 
mecânico. A menção a Hölderlin, no ensaio, se dá no universo do romance Hipérion, que expóe o despertar do jovem personagem por sua vocação poética em tempos de morte da poesia. Benjamin recria em seu ensaio esse ambiente, sobretudo no conhecido diálogo entre o gênio e a prostituta, no qual esta última exclama: "Dême sua mão, sua mão adormecida faz-me sentir que você esqueceu todos os poemas". Ao que responde o gênio: "Só consigo pensar em minha mãe. [...]. Ela me deu à luz. Como você, ela deu à luz a uma centena de poemas mortos" (Benjamin, 20I5, vol. III, p. 68).

Todo o universo da produção poética de Hölderlin orbita em torno da questão da morte do poeta na modernidade. Não apenas o Hipérion é construído em torno desse tema, mas também a tragédia inacabada $A$ morte de Empédocles, que tem por objeto o iminente suicídio do poeta no Etna, após ter sido expulso por seu povo de sua cidade, seguindo nisso a história contada por Horácio: “[...] e lhe contarei o fim do poeta siciliano: desejoso de passar por um deus imortal, Empédocles saltou, de sangue frio, nas chamas do Etna” (Horácio, I992, p. 68). Também nos hinos tardios, como em Páo e vinho, Patmos e Timidez, Hölderlin poetiza o declínio moderno dessa figura do poeta que, na Grécia antiga, era celebrada como mestre e educador da humanidade. Neste mundo ensurdecido pelas forjas bramantes, pelos ruídos dos automóveis e das fábricas, pela multiplicação infinita dos choques nas metrópoles, a palavra poética perde sua eficácia, seu poder de manter unidos homens e celestiais. Imersos numa modernidade sem poesia, os homens se fecham por um lado em seu próprio mundo da técnica e, por outro, os deuses se retraem num Olimpo longínquo, enquanto o poeta vive sua solidão melancólica, sem o reconhecimento e o apoio dos viventes, restando-lhe apenas a opçáo do suicídio ou o esquecimento da loucura, como se deduz das palavras do próprio Empédocles: "Onde estais, ó deuses? Ai, como um mendigo / Me abandonais a este peito...” (Hölderlin, 2008, p. 107). E mais adiante: "Agora choro como um rejeitado / E não gostaria de ficar em lugar algum!” (ibid., p. II5).

O tema da morte do poeta na modernidade constitui, assim, o pano de fundo hölderliniano que Benjamin retoma, buscando pensar a condição da juventude à beira da Primeira Guerra Mundial. Essa referência, no entanto, é ainda reforçada por um acontecimento biográfico, recorrentemente lembrado pelos comentadores. Em I9I4, seu grande amigo e poeta Fritz Heinle comete suicídio na conhecida Sprechsaal do Tiergarten, em Berlim, onde o grupo sionista da Jugendbewegung, do qual Benjamin fazia parte, se reunia semanalmente para discutir literatura, judaísmo e a reforma do sistema escolar-universitário alemão. O suicídio do amigo e poeta coincide com o estouro da Primeira Guerra e com a dissoluçáo do Jugendbewegung, 
fato este que ecoa fundo no espírito de Benjamin, como se pode ler em sua correspondência e nos relatos de Scholem. ${ }^{4}$ Este último, com efeito, não deixa de estranhar a reação de Benjamin que, diante da notícia do suicídio de Heinle, enclausura-se na Suíça, onde se pôe a ler Hölderlin, ocasião em que escreve o conhecido ensaio Dois poemas de Friedrich Hölderlin, no qual busca comparar duas versóes de um mesmo poema dedicado à condiçáo do poeta em tempos de indigência. Como afirma Alexander Honold, o ensaio como um todo constitui uma espécie de encômio a Orfeu, o poeta dos poetas que desce ao Hades e enfrenta os perigos do reino dos mortos em busca de sua amada (cf. Honold, 2000, p. 56).

O suicídio de Heinle, assim, representa para Benjamin mais do que a morte de seu amigo pessoal. Sua morte significa ao mesmo tempo a morte daquela geração na qual o próprio Benjamin, na Metafísica da Juventude, depositou toda a esperança de renovação da cultura alemã, por meio do vaticínio utópico do despertar do poeta e da poesia erótica na modernidade. É assim que Ernst Gumpert, amigo de Benjamin da época do Jugendkulturbewegung, afirma que a morte de Heinle representa a primeira baixa da guerra (cf. ibid., p. 6I), ao mesmo tempo em que sela o fim desse círculo que, reunindo-se em torno da figura de Gustav Wynenkens, pretendia renovar a cultura alemã por meio da criação de uma nova relação com o conhecimento. Quão decepcionado não ficaria Benjamin ao observar que essa mesma juventude seria agora tomada de entusiasmo pela guerra, e caminharia espontaneamente para a morte? Esse entusiasmo súbito pela guerra que inflou os ânimos da geração de I9I4 dá-se em larga medida por meio da influência exercida pelo poema Stern des Bundes, de Stefan Georg. Constituído de mais de cem poemas, o ciclo de Georg foi recebido por essa juventude como uma espécie de convocação à guerra, eleita a única forma possível de implementaçáo do Estado poético, de modo a superar o fosso milenar entre povo e cultura. Nessa toada, também Hölderlin e Rilke são invocados e suas obras levadas ao front, numa retomada do mote da aliança entre a "lira e a espada", de Theodor Körner, em Leyer und Schwert (cf. ibid., pp. 62-68). Tratava-se de um movimento semelhante ao que, décadas antes, havia eleito o Fausto de Goethe o herói nacional por excelência, e que agora proporciona uma edição de guerra do Hipérion de Hölderlin, como nota Hinrich Seeba:

A atual legitimação da germanística como portadora do escudo da política serviu à idealização do Fausto como herói nacional, que alcançou em I870 seu ponto primeiro culminante, assim como em I9Is a edição de campo [de batalha] do Hipérion de Hölderlin (apud Honold, 2000, p. 64).

Esse mesmo entusiasmo, originado no século XIX em torno de Goethe, e que ressurge com toda força no início do século XX em relação a Hölderlin, George e

\footnotetext{
4 Escreve Scholem: "Eu expus-lhe reservas contra o [periódico] Anfang e ele disse que havia deixado esse mundo que, com o estourar da guerra, havia desmoronado, particularmente porque a pessoa mais importante dela, seu amigo Heinle [...] tirou a vida alguns dias após o estourar da guerra com sua companheira” (Scholen, 2016, p. 19).
} 
Rilke experimentaria um renascimento no âmbito da Segunda Guerra, agora sob inspiração do livro de Max Kommerell, Der Dichter als Führer in der deutschen Klassik, de 1928. "Der Dichter als Führer" (o poeta como líder) seria, com efeito, o mote utilizado em prol de um Estado estético e Hölderlin figuraria novamente como poeta preferido. Seguindo as pegadas de Wilhelm Dilthey (cf. Das Erlebnis und die Dichtung, de 1905), também Kommerell interpreta Lessing, Goethe e Novalis como etapas de um complexo processo cujo ápice é o Hipérion de Hölderlin, romance que, segundo este autor, trata da "divinização de todo um povo na guerra" (Kommerel, apud Honold, p. 65). O objetivo de tal interpretação da obra de Hölderlin, como se vê, é sua veiculação propagandística em prol da utopia da guerra poética como forma de restauração da unidade mítica entre povo e cultura, entre homens e celestiais, unidade que, cantada e exaltada por Hölderlin em seus hinos, é aqui distorcida e mal interpretada.

O ensaio de Benjamin sobre os poemas de Hölderlin, assim, não pode ser visto como pertencendo apenas ao âmbito puro da crítica literária; sua intenção, embora não nomeada explicitamente, é também política e pode ser resumida como uma tentativa, empreendida no campo da crítica de arte, de combater a leitura estetizante de Hölderlin, propiciada de certo modo pelo círculo de Stefan Georg. ${ }^{5}$ Não por acaso, Benjamin encerra seu ensaio referindo-se a um princípio fundamental da poesia de Hölderlin que a interpretação esteticizante simplesmente ignora: o princípio da sobriedade junônica ou do elemento sacrossóbrio (heilignüchtern), característica que passa a dominar sua poesia do período tardio, escrita após I802, quando de seu retorno de Bordeaux. A sobriedade, aqui, torna-se uma exigência do poeta para a poesia moderna como um todo, cuja tarefa, entre outras coisas, consiste no combate ao entusiasmo poético desenfreado, ao furor poeticus a que se refere Horácio, manejado acriticamente por toda aquela geração em prol da aliança entre a poesia e a espada, e cujo efeito é o suicídio inevitável do poeta.

\section{A morte de Norbert von Hellingrath e a descoberta de Hölderlin}

Alguns anos depois do suicídio de Fritz Heinle, também Norbert von Hellingrath, o primeiro editor crítico das obras de Hölderlin, cai no campo de batalha de Verdun em 1917, com apenas 28 anos de idade. Responsável pelo renascimento da obra de Hölderlin no século XX, Hellingrath corrigiu com seu trabalho crítico-filológico uma grave falha da crítica e da historiografia da época, que por todo o século XIX silenciou sobre a obra do poeta suábio. Se, por um lado, o surgimento do ensaio de Benjamin

\footnotetext{
5 Neste ponto, é importante deixar claro que o próprio Stefan Georg ignorava essa interpretação que a juventude fazia de seus poemas, tal como aponta Robert Curtius: "George estava surpreso e descrente, quando eu o disse em i9i4 que ele era o herói dessa juventude. Ela levou o Stern des Bundes junto com ela para a guerra” (Curtius apud Honold, 2000, p. 63).
} 
sobre Hölderlin está ligado ao suicídio de Heinle, por outro, ele é também devedor da publicação, em I9I3, do primeiro volume da edição crítica das Obras Completas de Friedrich Hölderlin por Hellingrath. A grande novidade do empreendimento de Hellingrath em relação às ediçôes anteriores da obra de Hölderlin é que ela traz a publicação das traduções das odes de Píndaro, bem como dos hinos tardios, escritos entre 1802 e I806, ambos ainda inéditos até aquele momento. Hellingrath encontrou as traduçôes e os hinos por acaso nas bibliotecas de Stuttgart e Bad Homburg, quando pesquisava para sua tese de doutorado sobre as traduçóes que Hölderlin havia feito de Sófocles. ${ }^{6}$ Ora, em meio aos hinos contava justamente a segunda versão de Dichtermut [Coragem de Poeta], que Hölderlin intitulara Blödigkeit [Timidez], assim como Patmos, um dos hinos preferidos de Benjamin, cujas estrofes sobre a morte ele utiliza na abertura de seu livro de poemas dedicado ao amigo Heinle ${ }^{7}$ :

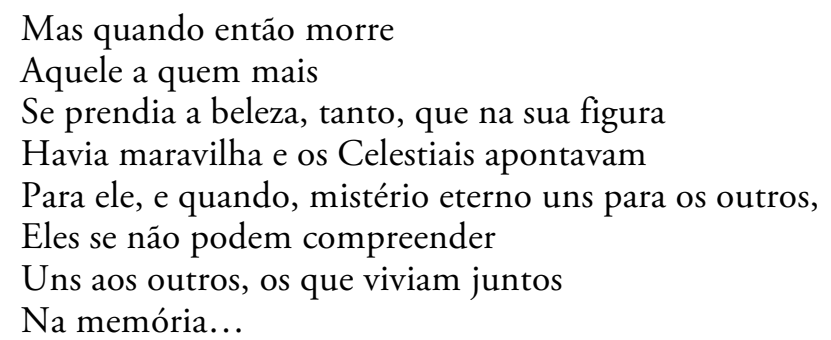

(Hölderlin, 1959, p. 373).

Se, por um lado, pode-se dizer que o surgimento dos Dois poemas de Friedrich Hölderlin de Benjamin está ligado à experiência da morte de Heinle e de Hellingrath, por outro, é preciso pontuar que essa experiência não é contada apenas como influência psicológica. $\mathrm{O}$ ensaio de Benjamin sobre Hölderlin é também devedor em larga medida do conteúdo do trabalho de Hellingrath sobre Hölderlin como um todo e pode-se dizer que foi decisivo para a constituição do conceito de crítica de arte de Benjamin, tal como este conceito é desenvolvido nos Dois poemas de Friedrich Hölderlin e em As afinidades eletivas de Goethe. O empreendimento de edição das obras completas de Hölderlin, publicada com o auxílio de um rico aparato crítico e filológicos, ocasiona um virulento debate com acadêmicos e críticos da época,

\footnotetext{
${ }^{6}$ As traduçôes de Hölderlin, tanto de Sófocles como de Píndaro, são mencionadas por Benjamin no ensaio A tarefa do tradutor e pode-se dizer que estáo no centro de sua teoria da linguagem: "As traduçóes de Hölderlin sáo arquétipos [Urbilder] da sua forma: elas estáo para as mais perfeitas versóes daqueles textos como o arquétipo está para o modelo [Vorbild], como mostra a comparaçáo das traduçóes da terceira ode pítica de Píndaro por Höldelrin e Borchardt. Por isso mesmo lhes é inerente, mais do que a outras, o enorme perigo, ameaça original de todas as traduçóes: que os portóes de uma língua assim alargada e dominada se fechem, encerrando o tradutor no silêncio" (Benjamin, 20I8, p. IOO).

7 Estes mesmos versos de Hölderlin são citados por Scholem no discurso em memória da morte de Franz Rosenzweig, publicado como posfácio à ediçấo alemã de Der Stern der Erlösung (cf. Rosenzweig, 1996, pp. 522549). Benjamin também utiliza alguns versos de Patmos, de Hölderlin, na abertura da segunda parte do ensaio As afinidades eletivas de Goethe (cf. Benjamin, 20I8, p. 55), o que evidencia, como se verá a seguir, a relação íntima entre este ensaio e o ensaio sobre Hölderlin.
} 
sobretudo com aqueles que defendiam que os poemas tardios de Hölderlin não possuíam valor literário por serem apenas efeito da loucura que acometera o poeta a partir de I802. É assim que, por exemplo, Wilhelm Lange afirma, em Hölderlin: eine Patographie, de 1909, que o poema Blödigkeit (Timidez) "apresenta todos os sinais da dementia precox" (apud Primavese, in: Lindner, 20II, p. 466) de Hölderlin, e que todas as novas versóes de poemas escritos posteriormente a 1802 seriam oriundas $\mathrm{da}$ loucura, constituindo, portanto, apenas degeneraçóes das versóes originais, sem valor poético-literário.

Os trabalhos filológicos de Hellingrath sobre Hölderlin procuram justamente rebater esse tipo de interpretaçáo, que se baseia nos problemas pessoais do poeta para recusar a produçáo de toda uma fase de sua poesia. É assim que a ideia de comparaçáo dos dois poemas, Dichtermut e Blödigkeit, vem do próprio Hellingrath que, em sua tese intitulada Pindar-Übertragungen von Hölderlin, de I9ı, escreve: "Compare-se Blödigkeit com a primeira versão de Dichtermut, como ali cada modificação dá às passagens uma existência completa" (apud Honold, 2000, p. 57). Por meio da comparação, Hellingrath propóe que Blödigkeit, versão posterior de Dichtermut, aperfeiçoa o núcleo poético da primeira versão, invertendo a lógica de Lange de que a primeira versão seria mais valiosa poeticamente por não apresentar ainda traços da loucura. Benjamin, por sua vez, acolhe em seu ensaio a sugestáo de Hellingrath de comparar as duas versôes do poema, de modo a mostrar igualmente que a segunda versão aperfeiçoa aquilo que, na primeira, aparece como "uma notável indeterminação" (Benjamin, 2013, p. 24). Em seu ensaio, porém, Benjamin ultrapassa em muitos aspectos o método de Hellingrath, sobretudo ao abandonar a abordagem filológica do mestre, que se limitava a um exame da forma, e proporcionar ao estudo uma abordagem estética, de caráter filosófico:

O comentário foi reservado quase que exclusivamente às grandes obras da época clássica e, quando se dirigiu a outras obras que não as do drama clássico, foi muito mais de caráter filológico do que estético. Aqui deve-se realizar um comentário estético sobre duas composições líricas... (ibid., p. I3).

Somente uma abordagem estética, de teor filosófico, seria capaz de responder às críticas provenientes das interpretaçóes patográficas, como a de Lange, ou mesmo as psicológicas, muito comuns na interpretação da obra de Dostoievski ${ }^{8}$, por exemplo, todas elas baseadas numa relaçáo causal entre vida e obra ou entre forma e conteúdo. ${ }^{9}$ Ao desenvolver esse fundamento filosófico da crítica de arte a partir da

8 Benjamin se opóe à leitura psicológica da obra de Dostoievski no ensaio O idiota de Dostoievski cujo método de crítica mostra-se em estreita sintonia com o ensaio sobre Hölderlin e com o ensaio sobre Goethe, como se verá adiante. Neste ensaio mencionado, escreve: "A psicologia das personagens dostoievskianas [...] não é em absoluto aquilo que constitui o ponto de partida do escritor" (Benjamin, 20I3, p. 73).

9 Essa crítica ao método tradicional da crítica, que procura abordar a obra a partir da relação causal entre forma e conteúdo, vida e obra, autor e leitor, será retomada em chaves muito diferentes ao longo da obra de Benjamin, como se vê, por exemplo, em Rua de mão única, fundado sobre a ideia de que a literatura deixou a página impressa do livro e da escrita tradicionais, ou mesmo em $O$ autor como produtor, de 1934, que, em 
intepretação de Hellingrath sobre Hölderlin, Benjamin chega a um dos conceitos centrais de seu método, o conceito de teor [Gehalt] da obra de arte, nomeado na abertura do ensaio: "Busca-se, nestes poemas, expor a forma interna, aquilo que Goethe designava por teor" (Benjamin, 2013, p. 13).

O conceito de "teor de verdade" da obra de arte constitui de fato o núcleo de sua concepção de crítica de arte e seria desenvolvido de forma mais aprofundada em As afinidades eletivas de Goethe, inteiramente baseado nessa distinção. Porém, o esboço desse método já se encontra no ensaio sobre Hölderlin, no contexto de sua crítica à interpretação psicológica de Lange. No início deste ensaio, com efeito, Benjamin estipula a distância de sua interpretação em relação a essa abordagem, ao escrever que o presente estudo busca pela "forma interna do poema", e que o seu objetivo consiste em "estabelecer a tarefa poética como condição para uma avaliação do poema” (ibid., pp. I3-I4). A condição para avaliação do poema deixa, assim, de ser a vida pessoal do poeta, crítica que visa também o ensaio Das Erlebnis und die Dichtung, de Dilthey, perpassado pela concepção de que as modificaçôes sofridas pela vivência (Erlebnis) do poeta se traduzem em modificaçóes da estrutura de sua produção poética: "Essas modificaçóes na vivência do poeta modificaram sua relação com os objetos e gêneros da poesia, e cada um desses gêneros recebe por meio dela uma outra estrutura" (Dilthey, I92I, p. 9). É assim que, por exemplo, Dilthey explicava por que o gênero poético mais propício da modernidade é a tragédia, já que somente o trágico exprime em toda sua profundidade o embate político da $A u f-$ klärung contra o fanatismo religioso. Aplicando o mesmo método ao Hipérion, afirma Dilthey: "A forma artística da obra surge de sua tarefa de expor o significado da vida no material dos acontecimentos" (ibid., p. 260).

\section{A morte do poeta em Dois Poemas de Friedrich Hölderlin}

Contrariamente a este tipo de interpretação, Benjamin, em seu ensaio, procura antes explicitar a relação entre poesia e vida por meio dos elementos internos ao próprio poema, por uma referência a seu "cosmos": "Nada do processo de criação lírica, nada da pessoa nem da visão de mundo do autor será aqui investigado, mas sim a esfera particular e única na qual repousa a tarefa e a condição do poema" (2013, p. I4). Essa esfera particular e única Benjamin denomina "o poetificado" (das Gedichtete), expressão da unificação sintética e orgânica entre a ordem intelectual e a intuitiva. O poetificado é um conceito estético-filosófico que, ultrapassando a separação clássica entre forma e conteúdo, permite comparar dois poemas entre si a partir da noção de "tarefa poética", evidenciando o grau de aproximação de cada uma

favor de um tratamento dialético da crítica, propōe uma transposição da técnica fotográfica na técnica literária e vice-versa, a legenda na fotografia: "Temos que exigir dos fotógrafos a capacidade de colocar em suas imagens legendas explicativas que as liberem da moda e lhes confiram um valor de uso revolucionário. Mas só podemos formular convincentemente essa exigência quando nós, escritores, começarmos a fotografar" (Benjamin, 2008, p. 129). 
das versôes em relação ao ideal a priori da arte. ${ }^{10} \mathrm{~A}$ partir desse método, o ensaio procura evidenciar que a segunda versão do poema se aproxima mais do ideal a priori da poesia que o primeiro, isto é, que Blödigkeit logra uma concepção mais perfeita e mais completa do poetificado, da unificação indissolúvel entre forma e matéria:

Enquanto categoria de investigação estética, o 'poetificado' se distingue de modo decisivo do esquema forma-matéria por conservar em si a unidade estética fundamental de forma e matéria e, ao invés de separá-las, cunha sua ligação necessária, imanente (ibid., p. I5).

Entendido como unidade necessária e imanente entre forma e conteúdo, por meio do poetificado Benjamin ultrapassa o método da crítica tradicional, que lida com a separaçáo estanque entre essas duas instâncias, a forma sendo vista como causa do conteúdo ou vice-versa. Com isso, a derivaçáo causal, própria desse método tradicional, da obra a partir da vida perde sua força. Pois, como observa Benjamin ainda na introduçáo ao ensaio, por meio do conceito de poetificado, "a vida se determina através do poema", isto é, "não é a atmosfera da vida individual do artista que está na base, mas sim um conjunto de relaçôes vitais determinado pela arte" (ibid., p. I6). Antes de ser determinado pela vida individual do poeta, o poetificado surge como a unificação perfeita do conjunto de relaçôes vitais a partir do qual a arte cria a própria vida, num sentido muito próximo do mito, entendido como uma unidade artístico-sintética dos elementos que perfazem a vida. Baseado na noção do poetificado, assim, esse novo método da crítica visa atingir o elemento propriamente mítico do poema, considerado uma expressão da própria vida, bem como verificar a distância que separa os poemas particulares, Dichtermut e Blödigkeit, do ideal $a$ priori da poesia tal como contido no poetificado puro: "Depois de tudo o que foi dito, a explicitação do 'poetificado' puro, da tarefa absoluta, tem de permanecer uma meta no plano das ideias, puramente metodológica” (ibid., p. I8).

Segundo Benjamin, "na primeira versão de seu poema, Hölderlin tem como objeto um destino: a morte do poeta. Ele canta as fontes da coragem para enfrentar essa morte" (ibid., p. 24). Porém, nessa primeira versão, "a representação da morte não flui de um contexto puro, configurado", pois "a própria morte ainda não é - como será entendida mais tarde - figura em sua mais profunda coesáo”. Antes, a morte surge aí como "extinção da essência plástica, heroica, na beleza indeterminada da natureza” ou, em outros termos, a primeira versão expóe "um mundo fragilmente articulado que desfalece em beleza" (ibid., p. 26). O tema do poema - a morte do poeta - extingue-se, nessa primeira versão, na noção de bela aparência,

\footnotetext{
${ }^{10}$ Esta noção de ideal a priori da arte, que define a tarefa poética a ser realizada por toda obra particular, é central em $O$ conceito de crítica arte no romantismo alemão, que Benjamin publica em 1920. Trata-se de um conceito retirado dos autores do romantismo de Iena, e que, por sua vez, está ligado à ideia de crítica de arte como médium-de-reflexão da arte. A tarefa da crítica, nesse sentido, consiste nấo em julgar as obras particulares a partir de uma teoria exterior a ela, mas em dissolver sua forma na Ideia da absoluta da arte, por meio do médium-de-reflexão. Cf. para isso Benjamin, 1993, pp. 94-II4.
} 
que surge como forma de embelezamento dessa mesma morte, ocultando sua concretude efetiva. Em vez de aparecer como um fato da vida, a morte, na primeira versão, é representada esteticamente na forma bela. A principal causa desse modo de tratamento da morte do poeta nessa primeira versão é que "o poema vive no mundo grego, é animado por uma beleza próxima daquilo que é grego, e é dominado pela mitologia dos gregos" (ibid., p. 25). Enquanto tal, ele não logrou obter ainda um mito próprio, não derivado da mitologia grega, como acontecerá na segunda versão, que o faz por meio da inserçáo do elemento oriental, sobretudo nos versos "Não anda sobre o verdadeiro teu pé, como sobre tapetes? ["Geht auf Wahrem dein Fuss nicht, wie auf Teppichen?”]. Na segunda versão, assim, "o amparo na mitologia [grega] dá lugar à construção de um mito próprio” (ibid., p. 3I), constituído por meio de uma exposição mais sóbria daquilo que, na primeira versáo, apresentava-se ainda como esmorecendo diante da bela aparência.

A construção desse novo mito, na segunda versão, desvinculado do mito grego, tem duas etapas: a reconfiguração da relação do poeta com os viventes (o povo) e a reconfiguração da relação do poeta com os deuses. No que se refere ao primeiro elemento, trata-se de um tema caro à poesia de Hölderlin como um todo, constituindo uma das bases da peça $A$ morte de Empédocles, por exemplo, em que a morte iminente do poeta deriva do enfraquecimento de sua relação com os viventes. ${ }^{11}$ Benjamin, em seu ensaio, aponta para o fato de que essa ligação exerce um papel central nos dois poemas analisados, porém, ela aparece de forma diferente em um e no outro. Enquanto, na primeira versão, o poeta surge como aparentado [verwandt] ao seu povo, na segunda, ele se torna conhecido [bekannt] por ele, de modo que se estabelece, na segunda versão, uma dependência entre o poeta e o povo que, na primeira versão, não existia. O que funda o caráter mítico próprio dessa segunda versão é que essa dependência entre poeta e povo surge de uma forma tão íntima que ela se transforma no próprio destino. Por meio dessa ligação mais íntima entre o poeta e os viventes, na segunda versão, estes passam a deter o destino do poeta, que, portanto, não reside mais nas mãos dos divinos:

A atividade do poeta se encontra determinada pelo contato com os viventes [...]. É como signo e escrita da extensão infinita de seu destino que o povo existe [...]. É assim que, na qualidade de símbolo do canto, ao povo caberá realizar o cosmos de Hölderlin (ibid., p. 34).

Se, por um lado, o destino do poeta passa a estar nas máos do povo, por outro, isso ocorre porque há um retraimento dos celestes, na linha do universo poético que

\footnotetext{
${ }^{11}$ Em O Narrador, Benjamin ainda pensa o escritor a partir dessa relação — extraída de Hölderlin — entre o poeta e o povo. É essa ligaçáo que o narrador, ao contrário do romancista, deve buscar, como se vê, por exemplo, em Leskov: "Segundo Gorki, 'Leskov é o escritor ... mais profundamente enraizado no povo, e o mais inteiramente livre de influências estrangeiras'. O grande narrador tem sempre suas raízes no povo, principalmente nas camadas artesanais" (Benjamin, 2008, p. 214).
} 
marca a produção da fase tardia dos hinos de Hölderlin. Enquanto, na primeira versão, a coragem do poeta baseava-se na confiança propriamente grega em relação ao mundo divino, na segunda, essa confiança ou coragem se dissipam, e se tornam $T i$ midez (Blödigkeit), devido ao fato de que o deus se ausenta completamente da vida do poeta. Tal afastamento do divino, na segunda versáo, é marcado pela plasticidade imagética com a qual é dotada a representaçáo do divino, que faz com que o Deus se torne um mero objeto para o intelecto e o pensamento do poeta. $\mathrm{O}$ processo de configuração imagética dos deuses conduz à objetivação de suas figuras antes vivamente presentes, transformando-os agora em figuras mortas. Como afirma Benjamin, agora "o deus deixa de determinar o cosmos do canto", isto é, o universo poético deixa de ser comandado pelo divino. E "quando o deus torna-se objeto em sua infinitude morta, o poeta dele se apossa” (ibid., p. 42), tornando-se mestre de seu próprio destino poético. Esse processo consuma, assim, a eliminação do mito grego e a instauração de um mito próprio. Aquilo que, nas Observaçôes sobre Édipo, Hölderlin denomina "afastamento categórico" do deus e do homem", aqui é evidenciado por meio da hybris entendida como a figuraçáo de si mesmo e que, em última análise, representa a morte do divino em sua forma grega. Ao declinar de sua forma própria, o Deus grego deixa de possuir controle sobre o canto, que, assim, é assumido pelo próprio poeta. E tendo os deuses abdicado do domínio do mundo poético, "a um outro cabe ocupar o centro deste mundo" (ibid.): o próprio poeta, não mais protegido dos perigos do mundo pelo divino, mas o poeta como ser sensível que se póe diante dos perigos da morte. E é assim que, na segunda versão, "o mundo do herói morto é um mundo novo, mítico, saturado de perigos” (ibid., p. 45).

Diferentemente da primeira versão, em que a morte do poeta figura como destino, num sentido propriamente grego, na segunda, as rédeas do destino são dominadas pelo próprio poetificado, numa inversão da relaçáo propriamente grega. Agora, não é o destino que comanda o poeta, mas o próprio poeta tem o destino em suas mãos e pode, assim, pôr-se de modo verdadeiramente corajoso diante dele:

Na morte, que é o seu mundo, estão unificadas todas as relaçôes. Nela estão presentes a mais extrema forma infinita e a ausência de forma, plasticidade temporal e existência espacial, ideia e sensibilidade. E cada função da vida nesse mundo é destino, ao passo que na primeira versão do poema o destino, segundo a concepção tradicional, determinava a vida (ibid.).

Enquanto, na primeira versão, o destino comanda a vida do poeta, na segunda, o poeta, por meio do poetificado, que unifica todas as relaçóes, domina o destino,

12 "Neste momento, o homem esquece de si e do deus e se afasta, de um modo certamente sagrado, como um traidor. No limite extremo do sofrimento não restam, com efeito, senão as condiçôes do tempo e do espaço. Neste limite, o homem esquece de si mesmo, porque ele está totalmente no momento; o deus, porque é apenas tempo; e ambos são infiéis, o tempo, porque vira em tal momento categoricamente, e início e fim simplesmente deixam de rimar nele; o homem, porque deve neste momento seguir o afastamento categórico, sem poder, por conseguinte, se igualar ao que era no início" (Hölderlin, I994a, p. 856). 
o que altera também sua relação com a morte. Na primeira versão, o poeta encontrava-se determinado pela morte enquanto destino inescapável, o que o fazia temêla; na segunda versão, tendo-a dominado, ele pode encará-la de modo verdadeiramente corajoso, isto é, de forma passiva, que é a forma da timidez: "'Timidez' essa passa a ser agora a autêntica atitude do poeta" (ibid., p. 46). E é assim que “o princípio do 'poetificado' em geral é a soberania exclusiva da relação que nesse poema em particular é figurada como coragem" (ibid., p. 45). Enquanto, na primeira versão, a morte determinava a vida desde fora, agora, na segunda, a morte é trazida para o interior do poema, por meio do poetificado, permitindo ao poeta tomar o controle sobre ela. Do mesmo modo, enquanto, na primeira versáo, seu corpo estava à mercê dos deuses, agora, por meio do poetificado, o poeta volta a ser portador do próprio corpo, elemento que aparece na terceira estrofe de Blödigkeit, segundo Benjamin, a estrofe central do poema: "e dos celestiais / Trazemos um. Porém, I Trazemos atinadas mãos nós mesmos” [,und von den Himmlischen / Einen bringen. Doch selber / Bringen schickliche Hände wir"] (ibid., p. 46, grifo meu). As "atinadas mãos”, tradução de „schickliche Hände“, apontam justamente para o processo de dominação do destino, que passa a estar nas mãos do próprio poeta.

\section{Morte e destino na modernidade}

Benjamin encerra seu ensaio sobre Hölderlin chamando a atenção para o elemento sacrossóbrio que marca a segunda versão do poema, como se disse anteriormente, e que está ausente da primeira versão, ainda demasiado grega por sua relação com o destino: "precisamente o elemento grego encontra-se suprimido da última versáo e substituído por outro que (a bem da verdade, sem uma justificativa explícita) denominamos oriental" (ibid., p. 48). Náo é aqui o caso de aprofundar o significado desse elemento oriental que Hölderlin, na segunda versão do poema, situa no lugar do mito grego, mas apenas apontar para sua característica central: a sobriedade. Em oposição ao furor poeticus, própria da poesia grega, de origem homérica, o elemento sacrossóbrio do poema permite que o poeta tome o controle de seu destino, antes situado nas mãos dos deuses. Benjamin, em seu ensaio, procura mostrá-lo por meio de seu conceito de poetificado, pelo qual o poeta sintetiza os elementos mais fundamentais da vida e os expõe numa imagem poética indestrutível. Esta imagem poética não é propriamente mítica nem mitológica, no sentido grego, mas uma imagem das "ligaçôes míticas que a obra de arte plasma numa figura única" (ibid.). Em última análise, o poetificado expóe, por meio do poema, os fios que constituem a própria vida do poeta, cuja característica central, na modernidade, é a sua relação com a morte. Por meio da comparação de Dichtermut e Blödigkeit, Benjamin mostra que Hölderlin, na segunda versão, foi ao encontro do princípio que domina seus hinos tardios como um todo: o princípio da sobriedade que, em última instância, é o estado de espírito com o qual o poeta moderno de uma forma em geral deve se pôr 
diante da morte, aceitando assim seu destino. Só então seu estado de ânimo deixa de ser a coragem do que se opóe ao destino, para se tornar a timidez daquele que o reconhece e o aceita. A sobriedade, que Hölderlin define como elemento oriental e anti-grego, consiste aqui em um exercício de aceitação do destino que, na modernidade, se revela por meio da morte do poeta.

Em Dois poemas de Friedrich Hölderlin, Benjamin sublinha essa exigência de Hölderlin por meio de uma comparação dos dois poemas mencionados, enquanto que, em outros textos, tal exigência vem à tona a partir de referências às Observaçóes sobre Édipo e Antígona, de I803-I804, também de Hölderlin. Referências a este ensaio aparecem, por exemplo, em $\mathrm{O}$ conceito de crítica de arte no romantismo alemáo (cf. Benjamin, 1993, p. I09) e em As afinidades eletivas de Goethe (cf. id., 2009, p. 93) e se concentram sobretudo no conceito de cesura, central no ensaio de Hölderlin. Definida como princípio métrico, a cesura tem por função a interrupção do ritmo do poema, possibilitando uma ruptura do efeito da bela aparência proporcionada pela arte grega. Nas palavras de Hölderlin:

[...] na sucessão rítmica das representaçóes, na qual o transporte se apresenta, se torna necessário o que na métrica se denomina cesura, a palavra pura, a interrupçáo antirrítmica, para enfrentar a mudança dilacerante em seu ponto culminante, de sorte que náo apareça mais a alternância da representaçáo, mas a própria representação (Hölderlin, I994a, p. 850).

A ruptura proporcionada pela cesura no ritmo do poema trágico garante a sobriedade do poeta que, nesse caso, aproxima-se do estado reflexivo do filósofo. Como afirma Benjamin: "a tese que funda sua relação [de Hölderlin] filosófica com os românticos é a proposição da sobriedade da arte” (Benjamin, I993, p. I08). Os filósofos românticos, contrariamente ao que se poderia supor, não são caracterizados pelo êxtase poético-sentimental, mas, pelo contrário, seu traço principal repousa precisamente no fato de que souberam encontrar na luz da consciência uma oposiçáo ao estado de sonho que a tudo engole e suprime. E "assim como nos primeiros românticos [...] a luz encontra-se como símbolo do médium-de-reflexão, da infinita clarificação da consciência, assim também Hölderlin diz: 'Onde estás tu, pensador!, que sempre tens que / Passar ao lado, em tempos, onde estás tu, luz?” (ibid.). A poesia de Hölderlin, prosaica em sua essência, constitui assim um esforço consciente de aproximação da reflexão filosófica, justamente porque a exigência fundamental que a governa é a da sobriedade da arte, em oposição ao estado delirante do poeta homérico. Que a garantia da sobriedade esteja ligada ao conceito de cesura mostra-o o ensaio As afinidades eletivas de Goethe, no qual escreve Benjamin, após citar a passagem acima das Observaçóes:

A "sobriedade junonal do ocidente" que Hölderlin [...] apresentava como meta quase inalcançável de toda prática artística alemã é apenas uma outra denominaçáo daquela cesura, na qual, simultaneamente com a harmonia, 
toda expressão se detém para dar lugar a um poder que é, no âmbito de todo meio artístico, sem expressão. Tal poder jamais foi mais evidente do que na tragédia grega, de um lado, e nos hinos de Hölderlin, de outro lado. Perceptível na tragédia como o emudecer do herói, nos hinos como protesto dentro do ritmo. Sim, náo se poderia definir de modo mais preciso esse ritmo do que com a afirmação de que algo para além do poeta interrompe a linguagem da poesia. Eis aqui o motivo "por que um hino raramente [...] será chamado de "belo"” (Benjamin, 2009, p. 93).

Ao interromper o ritmo das representaçóes do poema (trágico), a cesura garante a chamada "sobriedade junonal do ocidente" 13 , diferenciando o poema, assim, de todo modelo grego. Por meio da cesura, o poema abre espaço, no interior da obra de arte, para um "algo" que não pode ser representado por uma forma bela, no sentido grego do termo. A interrupçáo antirrítmica proporcionada pela cesura permite a irrupção, no interior do poema, de algo que está "para além do poeta", a saber, o "real" em toda a sua irredutibilidade representativa. É precisamente isso, no caso de Sófocles, que faz com que o poema seja propriamente trágico, na medida em que este "real" que irrompe por meio da cesura é o reino dos mortos que, como destino, envolve o herói e o enreda numa trama da qual ele não saberá se desprender. Ao mudar o tempo do poema, a cesura abre espaço para essa morte que, a partir de agora, não poderá mais ser refreada, justamente porque ela se apresenta como destino. Enquanto, porém, essa relação com o destino é natural aos gregos, ele não o é aos modernos, que, como define Hölderlin no Hipérion ${ }^{14}$, são caracterizados pela ausência de destino. Como se lê nas Observaçôes sobre Antígona:

[...] para nós, as representações gregas são diferentes na medida em que sua tendência principal é poder compreender a si mesma, porque nisso residia sua fraqueza, enquanto que, ao inverso, a principal tendência no modo de representaçáo de nosso tempo é poder atingir algo, ter um destino, pois a carência de destino, o $\delta v \sigma \mu o p o v$ é a nossa fraqueza. Por isso o grego possui mais habilidade e virtude atlética, e deve possuí-las, por mais paradoxal que possam

\footnotetext{
${ }^{13}$ A expressão "sobriedade junonal do ocidente", citada aqui por Benjamin, é utilizada por Hölderlin na famosa carta a Casimir Böhlendorff, de dezembro de I8oI, em que o poeta explica os motivos pelos quais os modernos não podem simplesmente tirar suas regras do modelo grego: "Acredito que, para nós, a clareza da exposiçáo é, originariamente, táo natural como foi, para os gregos, o fogo do céu. Por isso também é que os gregos se deixam ultrapassar mais pela bela comoção [...] do que pela presença do espírito homérico e seu dom de exposição [...] [Os gregos] foram [...], desde Homero, exímios quanto ao dom da exposição, pois esse homem extraordinário possuía uma alma suficientemente plena para apresar, em seu reino apolíneo, a sobriedade ocidental de Juno e, assim, apropriar-se verdadeiramente do estranho. Conosco dá-se o inverso. Daí ser táo perigoso abstrair as nossas regras artísticas, única e exclusivamente, da excelência grega" (Hölderlin, 1994a, p. I32).

${ }^{14}$ Hipérion, nesse sentido, pode ser definido como um herói sem destino; sua saga, exposta no romance, se apresenta como uma busca infinita por um destino, por algo que ele possa atingir. Ao contrário do grego, que tem sua virtude formada no confronto com um destino terrível, que Hölderlin ilustra por meio da figura de Hércules, o moderno, figurado no personagem de Hipérion, vaga sem meta, como, de resto, acontece também com o Édipo em Colono (que assim se torna um modelo perfeito para o personagem moderno). Hölderlin situa a "Canção do destino de Hipérion" como o ápice da jornada de seu personagem, momento em que ele toma consciência de sua condiçấo, como se lê na terceira e última estrofe: "Mas a nós foi-nos dado / Não repousar em parte alguma, / Desfalecem, caem / Os homens sofredores / Às cegas de uma / Hora pra a outra, / Como água atirada / De rochedo em rochedo, / Anos a fio para o Incerto" (I959, p. 59).
} 
parecer para nós os heróis da Ilíada, como sua excelência própria e autêntica virtude (Hölderlin, 1994a, p. 918).

Enquanto a eficácia do destino constitui uma característica do grego, o traço característico do moderno é precisamente o oposto, a carência de destino. O exame que Hölderlin realiza das peças de Sófocles, assim, se dá no sentido de buscar nelas o elemento que justamente falta aos modernos - a lei calculável da poesia - a qual permitirá a estes se equipararem aos antigos em termos de grandeza. Ao fazer um uso próprio de um princípio propriamente grego, o moderno descobre seu traço principal, em oposição ao grego. Tal traço principal, porém, só é definido nas Observaçôes sobre Antígona, como "infidelidade divina" e "afastamento categórico". Enquanto o mundo grego é marcado pela presença constante do divino, presença que faz de sua arte uma arte de apresentação do divino na bela aparência, o mundo moderno é marcado pela infidelidade e pelo afastamento categórico do divino, por seu retraimento, o que, por sua vez, acarreta no deslocamento do papel antes central do poeta na Grécia antiga. Como o Deus está retraído, afastado, o poeta perde sua função de mediador entre ele e o povo; a palavra poética, a mitologia, assim, deixa de constituir a espinha dorsal da cultura, tal como na Grécia antiga. Deslocado para a periferia da cultura, como Empédocles e Baudelaire, o poeta, agora, deve encarar a própria morte, por meio de seu canto. Não se trata mais, nessa sua condição, de cantar a harmonia com os celestes, como em Homero, mas de trazer à consciência — filosófica - sua condiçáo cindida, apartada do mundo dos divinos e assim, por meio do canto, dominar seu próprio destino que, como se viu em Timidez, não está mais nas mãos dos deuses. Para isso, é necessária uma forma específica de linguagem poética que, utilizando-se do princípio do "poetificado" e da cesura, seja capaz de alcançar uma exposição propriamente moderna de seu destino, a partir da subversão do modo grego de representação.

\section{Referências bibliográficas}

Benjamin, W. (1993). O Conceito de Crítica de Arte no Romantismo Alemão. Tradução de Márcio Seligmann-Silva. São Paulo: Iluminuras.

Benjamin, W. (2008). Obras Escolhidas. Magia e técnica, arte e política (vol. I). Traduçáo de Sergio P. Rouanet. São Paulo: Editora Brasiliense.

BENJAMIN, W. (2009). As afinidades eletivas de Goethe. In: BENJAMIN, W., Ensaios reunidos: escritos sobre Goethe. Tradução de Mônica K. Bornebusch, Irene Aron e Sidney Camargo. Sáo Paulo: Editora 34.

Benjamin, W. (2013). Dois poemas de Friedrich Hölderlin. In: Escritos sobre mito e linguagem. Tradução de Susana K. Lages e Ernani Chaves. São Paulo: Editora 34.

BENJAMIN, W. (2015). Ausgewählte Werke. Darmstadt: Wissenschafltiche Buchgesellschaft. 
BENJAMIN, W. (20I8). A tarefa do tradutor. In: BENJAMIN, W., Linguagem, Tradução, Literatura [Filosofia, teoria e crítica]. Traduçáo de João Barrento. Belo Horizonte: Autêntica.

Hölderlin, F. (2008). A morte de Empédocles. Tradução de Marise M. Curioni. São Paulo: Iluminuras.

HÖlderlin, F. (1959). Poemas. Tradução de Paulo Quintela. Lisboa: Atlântida.

Hölderlin, F. (1994a). Reflexóes. Tradução de Márcia C. de Sá Cavalcante e António Abranches. Rio de Janeiro, Relume Dumará.

HÖLDERLIN, F. (1994b). Sämtliche Werke und Briefe. Hrsg. von Jochen Schmidt. Frankfurt am Main: Deutscher Klassiker Verlag.

Dilthey, W. (192I). Das Erlebnis und die Dichtung. Lessing - Goethe - Novalis - Hölderlin. Paderborn: Salzwasser Verlag.

Honold, A. (2000). "Der Tod des Dichters: Hölderlin”. In: Der Leser Walter Benjamin - Bruchstücke einer deutschen Literaturgeschichte. Berlin: Verlag Vorwerks.

HORÁCIO (1992). Arte Poética. Tradução de Jaime Bruna. São Paulo: Cultrix.

LindneR, B. (20II). (Hrsg.). Benjamin Handbuch: Leben - Werk - Wirkung. Stuttgart/Weimar: Verlag J. B. Metzler.

SCHOLEM, G. (2016). Walter Benjamin - die Geschichte einer Freundschaft. Frankfurt am Main: Suhrkamp.

VACCARI, U. R. (20I3). “O destino em Hölderlin”. In: Rapsódia, vol. 7, pp. 9I-99. 